\title{
Article \\ Global Performance of Sustainable Thermal Insulating Systems with Cork for Building Facades
}

\author{
Sofia Malanho ${ }^{1, *(\mathbb{D})}$, Rosário Veiga ${ }^{1}(\mathbb{C})$ and Catarina Brazão Farinha ${ }^{2}$ \\ 1 Building Department, National Laboratory for Civil Engineering, 1700-066 Lisbon, Portugal; rveiga@lnec.pt \\ 2 CERIS, Instituto Superior Técnico, University of Lisbon, 1049-001 Lisbon, Portugal; \\ catarina.brazao.farinha@tecnico.ulisboa.pt \\ * Correspondence: smalanho@lnec.pt
}

Citation: Malanho, S.; Veiga, R.; Farinha, C.B. Global Performance of Sustainable Thermal Insulating Systems with Cork for Building Facades. Buildings 2021, 11, 83. https://doi.org/10.3390/buildings 11030083

Academic Editor: Cinzia Buratti

Received: 22 January 2021

Accepted: 19 February 2021

Published: 26 February 2021

Publisher's Note: MDPI stays neutral with regard to jurisdictional claims in published maps and institutional affiliations.

Copyright: (C) 2021 by the authors Licensee MDPI, Basel, Switzerland. This article is an open access article distributed under the terms and conditions of the Creative Commons Attribution (CC BY) license (https:// creativecommons.org/licenses/by/ $4.0 /)$

\begin{abstract}
Rehabilitation of facades may be carried out with the application of External Thermal Insulation Systems (ETICS). Their main contribution is the increase of the energy efficiency of buildings. In the literature, hygrothermal, impact and fire performance studies have been carried out on several systems with different insulation materials, such as expanded polystyrene, mineral wool and extruded polystyrene foam insulation. Due to the growing concern with the environment, systems are being developed with more sustainable and ecological materials, such as ICB (expanded cork). These type of boards are responsible for a negative impact in global warming potential, significantly improving the environmental benefits of their use. As these systems were recently introduced to the market, applications on site are very recent and their behaviour over time still unknown. In this research, the durability and global performance of more sustainable systems (with ICB) were analysed through an experimental campaign and compared with EPS (expanded polystyrene) systems. The results show that the systems with ICB obtained satisfactory global behaviour comparable with the EPS systems. The ICB sustainable systems analysed stood out in acoustic performance.
\end{abstract}

Keywords: ETICS; sustainable solutions; durability; compatibility; cork; expanded polystyrene

\section{Introduction}

To minimize the effects of climate change and global warming caused by the production and use of energy, the construction sector invested in the area of rehabilitation and the adoption of solutions to reduce energy consumption [1]. External Thermal Insulation Composite Systems (ETICS) can be seen as one of those solutions [2]. These systems are efficient solutions, versatile and easy to apply. Their application avoids the demolition of the walls to incorporate the thermal insulation, any significant effects on the inhabitants and the reduction of indoor areas [3].

ETICS are multicomponent systems, with different layers: adhesive, thermal insulation, mechanical fixings, base coat, mesh and finishing coat. Insulation is the component with the function of increasing thermal resistance, practically eliminating thermal bridges [2]. Thermal resistance depends on the type of insulation and on the thickness used [4]. In addition to reducing energy, these systems increase the thermal comfort of buildings [5] and in some cases also acoustic comfort. The contribution for sound insulation depends on the type of insulation: the tests carried out show that expanded cork agglomerate (here referred to as ICB) and mineral wool (MW) have relevant contributions, in contrast to expanded polystyrene (EPS) [4,6]. It has been proved in previous studies that, for systems with the same number of layers and with the same thickness of insulation, systems based on cork as insulation material (natural cork or expanded cork), due to lower thermal diffusivity, provide greater thermal delays than other insulating materials, such as extruded polystyrene (XPS) and mineral wool (MW) [7]. Systems with a greater thermal delay contribute to the improvement of the thermal performance of buildings, as they delay 
the heat loss or gain through the wall. Therefore, cork-based ETICS present better thermal behaviour than ETICS based on XPS or MW insulating materials when used in buildings exposed to variable thermal conditions, as is the case in temperate climatic conditions.

ETICS can be installed directly on existing external walls (with or without render), provided they are compatible.

These systems are developed as a kit, so the various components must be compatible with each other contributing to the overall good behaviour. The alteration of one component can change the performance of the system [8].

As ETICS are applied on external facades, they are subjected to severe hygrothermal variations $[9,10]$. Different ETICS components with distinct characteristics present different thermal conductivity and expansion coefficients. Base coat (component of, normally, 2 to $3.5 \mathrm{~mm}$ ) should be able to follow insulation deformation and have good impact resistance; however, for that, it is necessary to incorporate a mesh to acquire the necessary tenacity. The finishing coat is the last layer and is directly in contact with the environment. This component has decorative functions, namely, to maintain a good aesthetic aspect over time, and protective functions, namely, to contribute to resistance to impact. ETICS are systems vulnerable to impact, which can be caused by people or by objects thrown or kicked or due to adverse environmental conditions such as hail fall in regions where these storms occur. Studies of EPS and EPS with the addition of graphite demonstrated that there is a risk of those insulation materials exceeding the softening point when temperature is close to $70^{\circ} \mathrm{C}$, that is, under the influence of high intensity of solar radiation risk [11]. Therefore, in countries with high temperatures in summer, ETICS with EPS may present anomalies due to deformation of the insulation material.

Another function of the finishing coat is water penetration resistance. Water absorption increases thermal conductivity of the insulation, reducing the ETICS performance; thus, protection provided by the finishing system is important. However, it should not excessively reduce water vapor permeability [12].

Often, the most used systems are the ones that incorporate EPS (expanded polystyrene) or XPS (extruded polystyrene foam) insulations [6] and a base coat composed of cementbased mortar. These insulation materials (EPS and XPS) are, in general, chosen for presenting a low price in comparison with other solutions, namely some more sustainable insulation materials. Some comparatives studies between EPS-based and MW-based (Mineral Wool) ETICS were made and found that the behaviour after hygrothermal cycles and bond strength were satisfactory $[8,13,14]$. However, they are responsible for great environmental impacts. For instance, a foam board of EPS is responsible for the emission of 65-94 $\mathrm{kg}$ [15-18] of $\mathrm{CO}_{2}$ equivalent ( $1 \mathrm{~m}^{3}$ declared unit) in the production phase alone, contributing significantly to the global warming potential (GWP). XPS also contributes to GWP impact. An XPS with a density of about $33 \mathrm{~kg} / \mathrm{m}^{3}$, in the production stage alone, emits about $92 \mathrm{~kg}$ of $\mathrm{CO}_{2}$ equivalent [18].

On the other hand, new systems with more sustainable and ecological materials are being developed. Natural insulation materials, such as expanded cork agglomerate boards (ICB), are being used [19]. ICB, contrary to artificial polymer systems such as EPS or XPS, does not contribute to global warming potential (GWP) impact. On the contrary, this type of insulation material is responsible for a negative GWP impact, meaning that during the production stage the ICB system captures $\mathrm{CO}_{2}$ emissions, reducing GWP by $505 \mathrm{~kg}$ of $\mathrm{CO}_{2}$ equivalent [20]. This environmental benefit is due to the cork oak tree's (Figure 1), from which cork is extracted, $\mathrm{CO}_{2}$ caption. Thus, ICB, in terms of global warming potential, is considerably more sustainable than EPS or XPS. Moreover, cork-based systems also present particularly good characteristics for comfort improvement. In particular, they have an acoustic performance and thermal delay that are more favourable than systems based on more common insulation materials. 

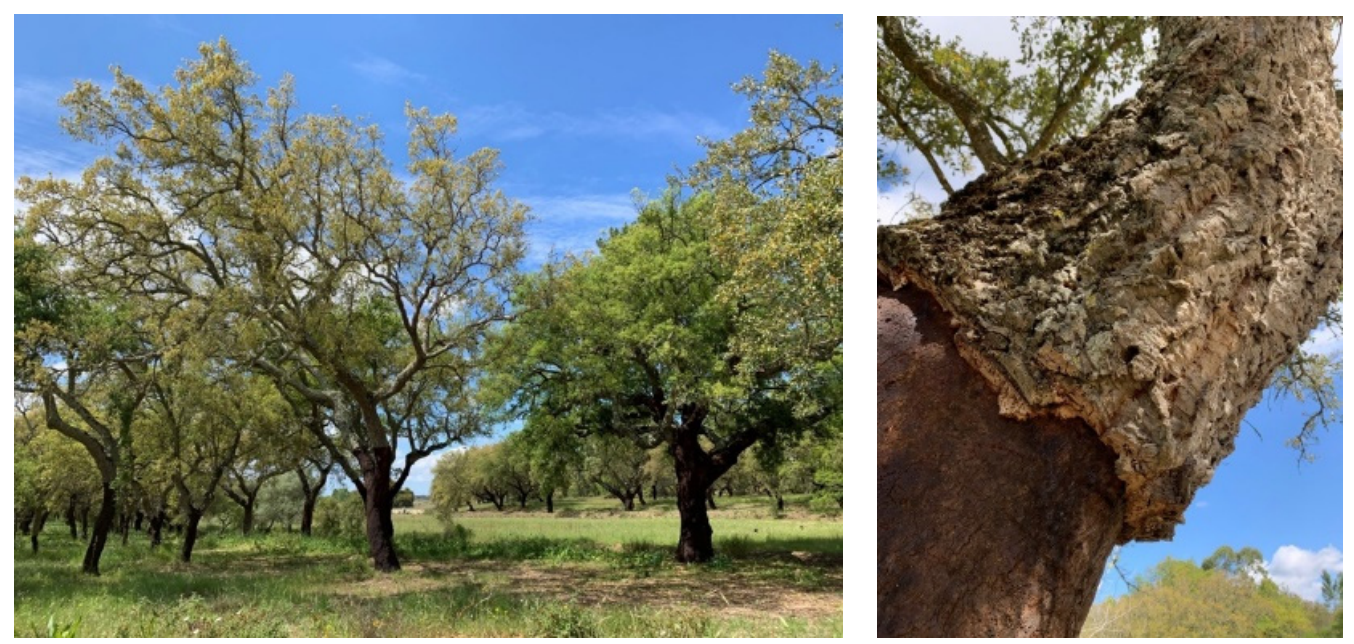

Figure 1. Cork oak tree.

Cork oak tree can be found in areas of the Western Mediterranean (Portugal, Spain, Southern France, part of Italy, North Africa) and in China. Europe produces $80 \%$ of world's cork [21], and Portugal is the world largest producer [22]. Due to the large production of cork and derivatives, ETICS with ICB were introduced in the Portuguese market a few years ago. Applications of these systems on site are still relatively recent, so performance over time is not yet well known. In the literature, there are a few ICB ETICS performance studies [23], and therefore, a large amount of research is still to be done on this topic.

In this research, we analysed 32 systems with different variables such as type of insulation (ICB vs EPS), base coat characteristics, number of meshes (one or double mesh) and type of mesh (standard or reinforced). Different tests were carried out to analyse water and mechanical behaviour, thermal and acoustic comfort, durability, artificial ageing and fire reaction.

The aim of the paper is the assessment of the global performance of sustainable ETICS with ICB and comparison with similar ETICS with EPS insulation.

\section{Materials and Methods}

\subsection{Materials}

In Table 1, ETICS studied are presented. In total, 32 different ETICS were analysed. Of these, 28 systems are bonded to the substrate (Figure 2a), and 4 systems have mechanical fixing (Figure $2 b$ ) with profiles and supplementary mechanical fastening (anchors) (Figure 2b-panel 7). The main characteristics of insulations, meshes, base coats and finishing coats are identified and are different according to each system. Some systems had some components in common. The insulations under analysis were expanded polystyrene (EPS) or expanded cork (ICB) (Figure 2a-panel 1), depending on the system. Some characteristics of the insulation materials, as tensile strength, bulk density, water vapour diffusion resistance factor, thermal conductivity and reaction to fire are presented in Table 1. Four types of mesh combinations were used, incorporated in the base coat (Figure 2a-panel 2) of the systems: normal (Figure 2a-panel 3), reinforced, normal and reinforced, or double reinforced. The reinforced mesh was characterized by a smaller opening dimension and higher mass per surface than the normal mesh. The adhesive and base coat were composed of the same mortar in each ETICS, although they have different functions: the adhesive (Figure 2a-panel 4) has the role of bonding the insulation product to the wall, while the base coat protects the insulation material, and the incorporated mesh is needed to improve its mechanical properties. In case of mechanical fixed ETICS, profiles were used to fix the insulation board (Figure 2b-panel 7). A general description of adhesives, base coats and finishing coats is also presented in Table 1. In some systems, more sustainable materials 
were applied such as a base coat mortar based on natural hydraulic lime and a finishing coat of a natural hydraulic lime based mortar plus a silicate based paint.

Table 1. Components characteristics.

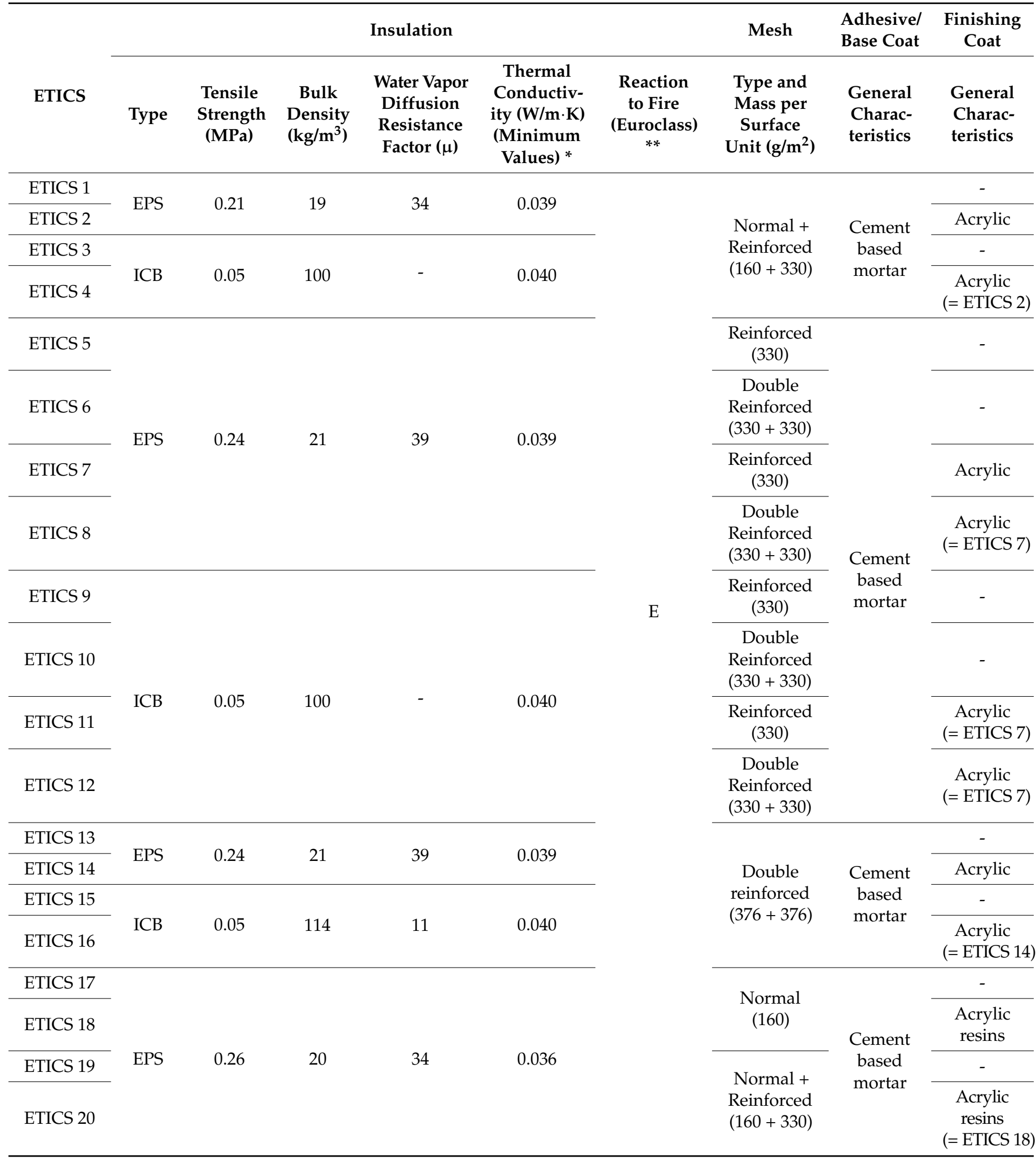


Table 1. Cont

\begin{tabular}{|c|c|c|c|c|c|c|c|c|c|}
\hline & & & & Insulation & & & Mesh & $\begin{array}{l}\text { Adhesive/ } \\
\text { Base Coat }\end{array}$ & $\begin{array}{c}\text { Finishing } \\
\text { Coat }\end{array}$ \\
\hline ETICS & Type & $\begin{array}{l}\text { Tensile } \\
\text { Strength } \\
\text { (MPa) }\end{array}$ & $\begin{array}{c}\text { Bulk } \\
\text { Density } \\
\left(\mathrm{kg} / \mathrm{m}^{3}\right)\end{array}$ & $\begin{array}{l}\text { Water Vapor } \\
\text { Diffusion } \\
\text { Resistance } \\
\text { Factor }(\mu)\end{array}$ & $\begin{array}{l}\text { Thermal } \\
\text { Conductiv- } \\
\text { ity (W/m·K) } \\
\text { (Minimum } \\
\text { Values) * }\end{array}$ & $\begin{array}{c}\text { Reaction } \\
\text { to Fire } \\
\text { (Euroclass) } \\
* *\end{array}$ & $\begin{array}{l}\text { Type and } \\
\text { Mass per } \\
\text { Surface } \\
\text { Unit }\left(\mathrm{g} / \mathrm{m}^{2}\right)\end{array}$ & $\begin{array}{l}\text { General } \\
\text { Charac- } \\
\text { teristics }\end{array}$ & $\begin{array}{l}\text { General } \\
\text { Charac- } \\
\text { teristics }\end{array}$ \\
\hline ETICS 21 & & & & & & & & & - \\
\hline ETICS 22 & & & & & & & & & 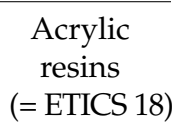 \\
\hline ETICS 23 & ICB & 0.05 & 100 & 24 & 0.040 & & $\begin{array}{c}\text { Normal } \\
(160)\end{array}$ & $\begin{array}{l}\text { Mixed } \\
\text { binders } \\
\text { based } \\
\text { mortar }\end{array}$ & $\begin{array}{c}\text { Natural } \\
\text { hydraulic } \\
\text { lime based } \\
\text { mortar }+ \\
\text { Paint } \\
\text { based on } \\
\text { silicate }\end{array}$ \\
\hline ETICS 24 & & & & & & & $\begin{array}{c}\text { Normal + } \\
\text { Reinforced } \\
(160+330)\end{array}$ & & - \\
\hline ETICS 25 & \multirow{4}{*}{ EPS } & \multirow{4}{*}{0.20} & \multirow{4}{*}{21} & \multirow{4}{*}{40} & \multirow{4}{*}{0.036} & & \multirow{2}{*}{$\begin{array}{c}\text { Normal } \\
(160)\end{array}$} & \multirow{4}{*}{$\begin{array}{l}\text { Cement } \\
\text { based } \\
\text { mortar }\end{array}$} & - \\
\hline ETICS 26 & & & & & & & & & $\begin{array}{c}\text { Acrylic } \\
\text { resins }\end{array}$ \\
\hline ETICS 27 & & & & & & & \multirow{2}{*}{$\begin{array}{c}\text { Normal + } \\
\text { Reinforced } \\
(160+330)\end{array}$} & & - \\
\hline ETICS 28 & & & & & & & & & $\begin{array}{c}\text { Acrylic } \\
\text { resins } \\
(=\text { ETICS 26) }\end{array}$ \\
\hline ETICS 29 & \multirow{4}{*}{ ICB } & \multirow{4}{*}{0.05} & \multirow{4}{*}{100} & \multirow{4}{*}{19} & \multirow{4}{*}{0.040} & & \multirow{3}{*}{$\begin{array}{c}\text { Normal } \\
(160)\end{array}$} & \multirow{4}{*}{$\begin{array}{c}\text { Mortar } \\
\text { based on } \\
\text { natural } \\
\text { hydraulic } \\
\text { lime, cement }\end{array}$} & - \\
\hline ETICS 30 & & & & & & & & & $\begin{array}{c}\text { Acrylic } \\
\text { resins (= } \\
\text { ETICS 26) }\end{array}$ \\
\hline ETICS 31 & & & & & & & & & $\begin{array}{l}\text { Air lime, } \\
\text { hydraulic } \\
\text { binder }\end{array}$ \\
\hline ETICS 32 & & & & & & & $\begin{array}{l}\text { Normal + } \\
\text { Reinforced } \\
(160+330)\end{array}$ & & - \\
\hline
\end{tabular}

* Thickness of the insulation board: $40 \mathrm{~mm}$. ${ }^{*} \mathrm{CE}$ marking.

\subsection{Methods}

Various aspects of the performance of external insulation systems for building walls were assessed, such as water transport and mechanical behaviour (impact and bond strength tests), acoustic and thermal comfort, durability (fundamentally mechanical tests after ageing) and fire performance (reaction to fire tests). In Table 2, the tests performed to analyse each type of behaviour are described, as well as the ETICS component analysed in each test, the age of test, the dimensions of the specimens and the requirements established according to ETAG 004 [2]. 


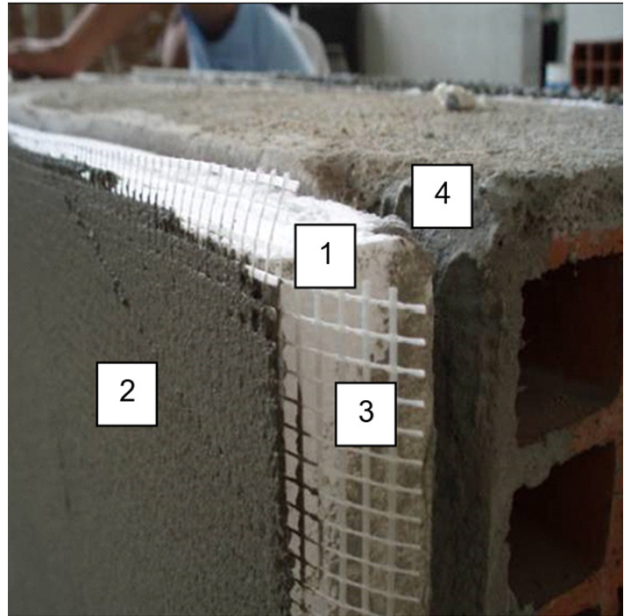

(a)

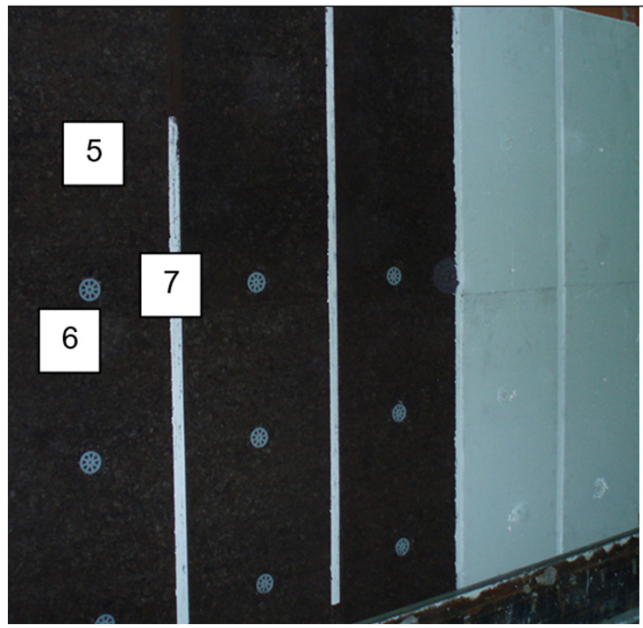

(b)

Figure 2. Bonded ETICS (identification of ETICS) (a) Mechanically fixed ETICS (b). 1-EPS, 2-base coat, 3-mesh, 4-adhesive, 5-ICB, 6-mechanical fixing and 7-profiles.

The water absorption (capillarity test) (Figure 3) was determined to analyse the resistance to water penetration; the samples without a finishing coat allow us to analyse if the base coat resists water penetration without the contribution of the finishing coat. The impact tests performed after the hygrothermal test are crucial, as the resulting category determines the field of application of the ETICS, namely the height from the ground of application of ETICS on the facade. The category is selected based on observations of the indentation visible on the surface after $3 \mathrm{~J}$ and $10 \mathrm{~J}$ impacts (Figure 4). Only systems with Category I can be applied close to the ground. The bond strength tests are important for analysing the bond between the base coat and insulation or between the adhesive and insulation (Figures 4-6).

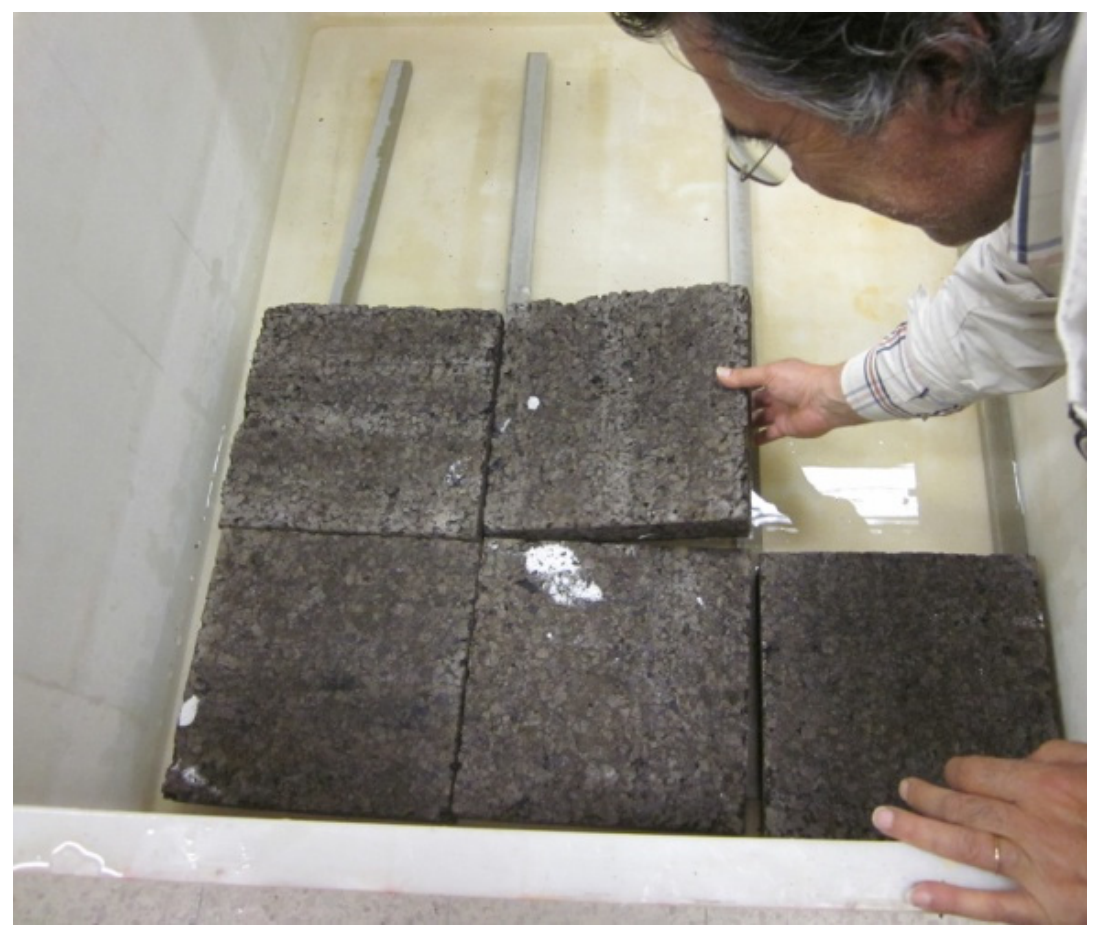

Figure 3. Capillarity test. 


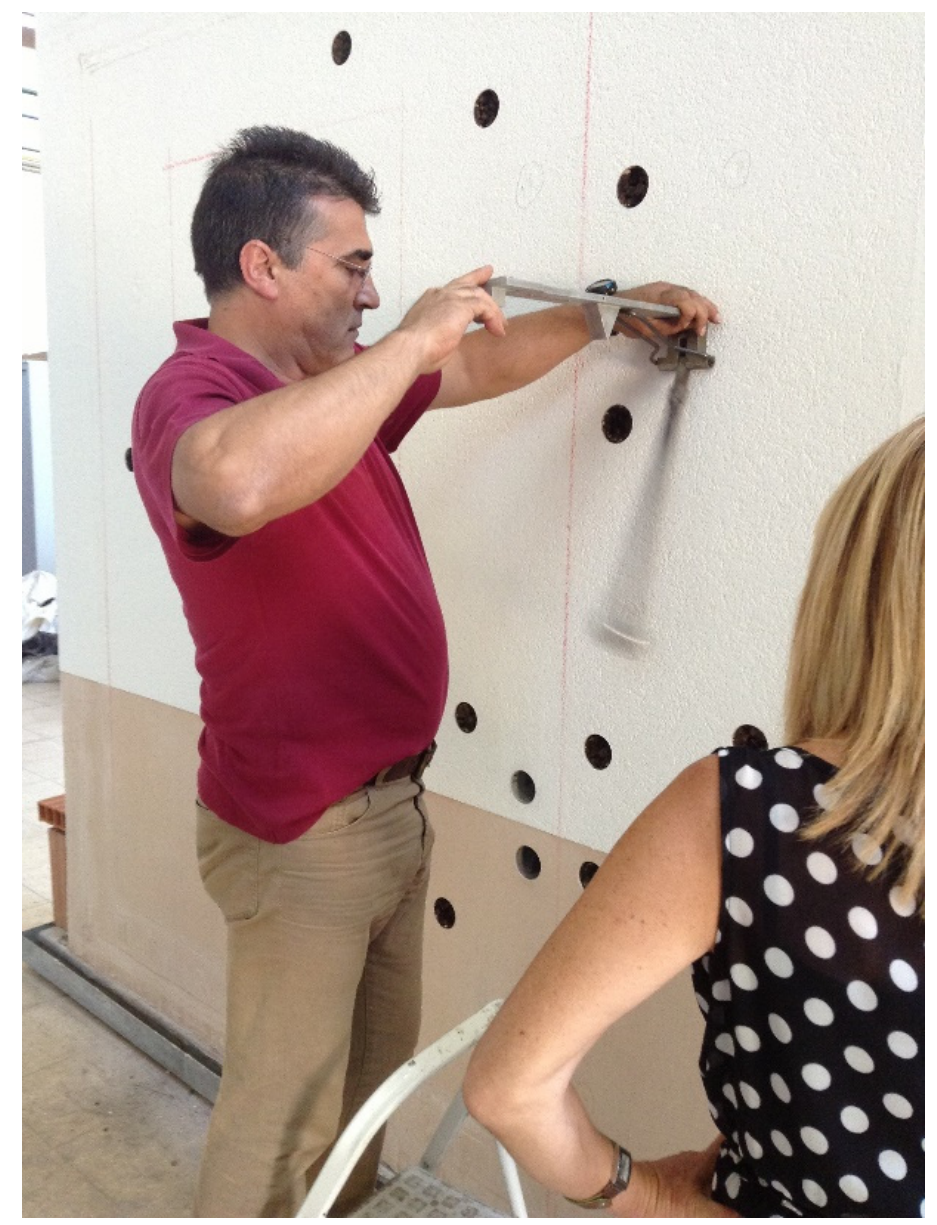

Figure 4. Impact resistance (3 J).

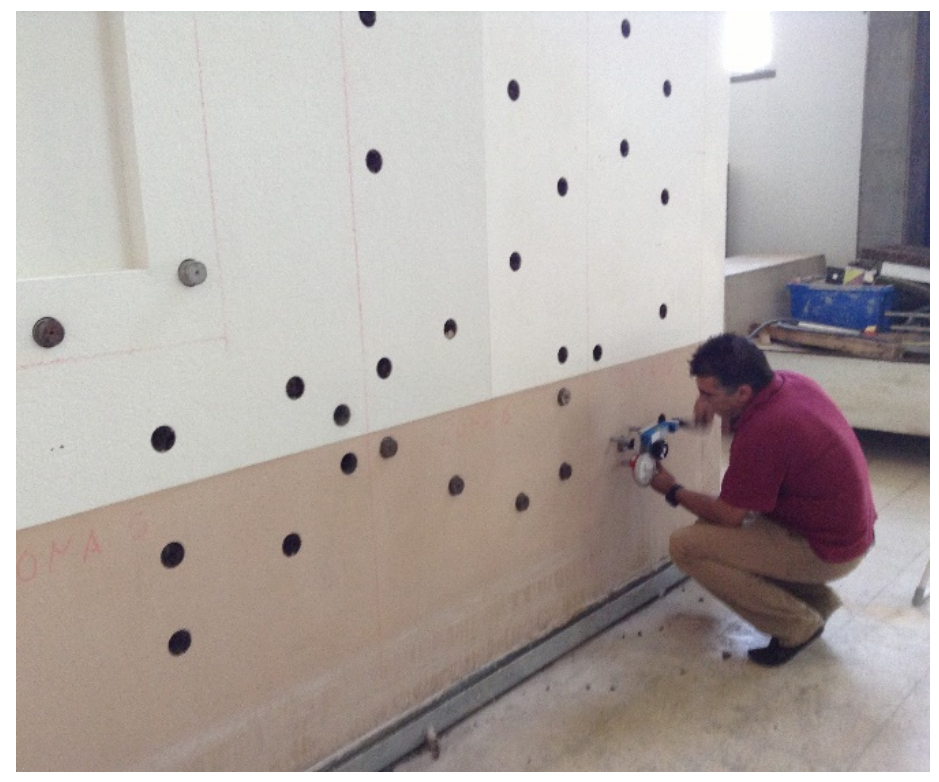

Figure 5. Bond strength test (in rig after hygrothermal test). 


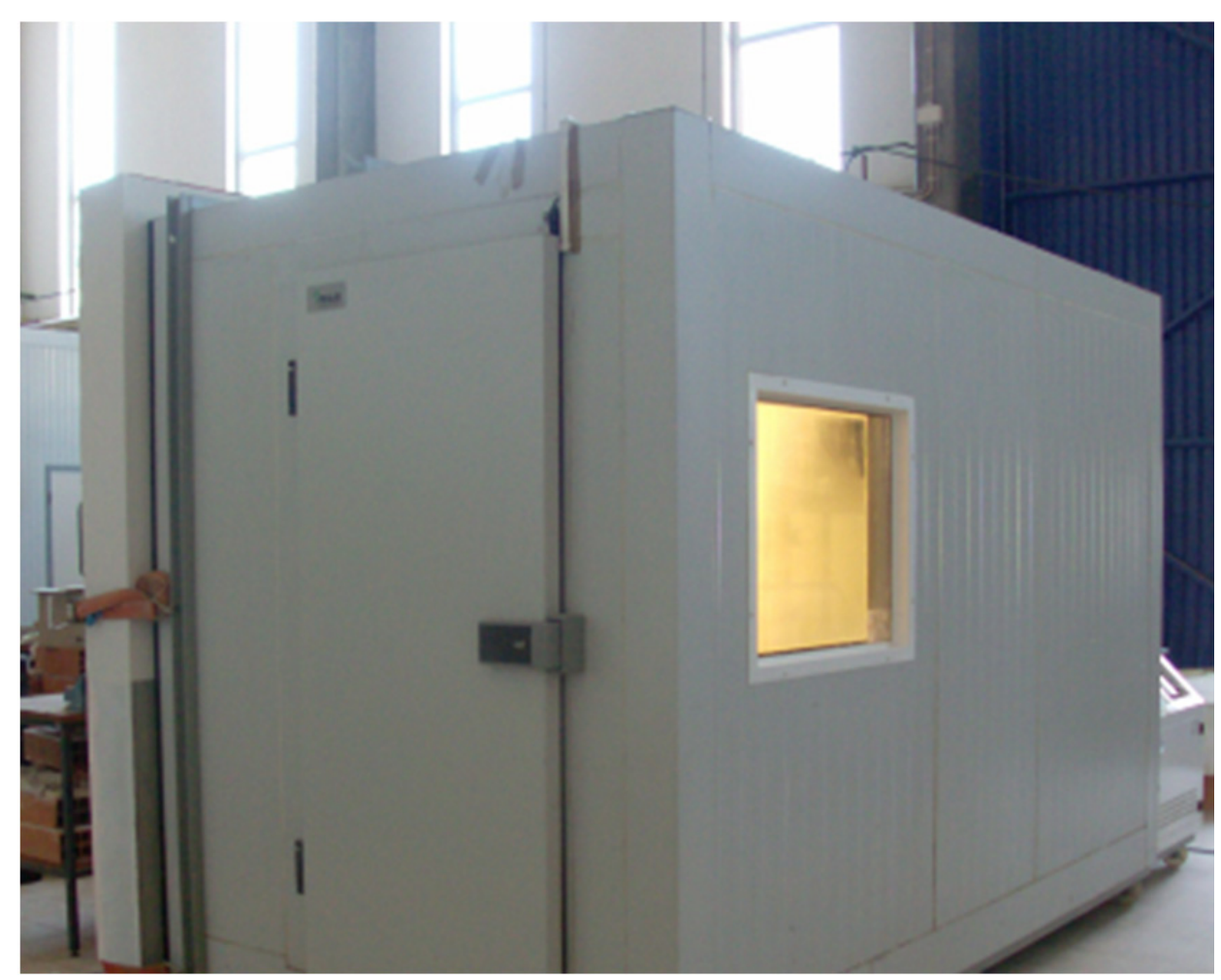

Figure 6. Hygrothermal test.

In some tests of the experimental campaign, applications of large dimensions of the systems (Table 2) were tested, aiming to be representative of real applications on facades in order to understand the behaviour of ETICS in situ. The tests were carried based on methods defined in ETAG 004 [2]. This Guideline sets out the performance requirements for ETICS. The analysis of results also took into account these requirements.

Table 2. Systems and components characteristics.

\begin{tabular}{|c|c|c|c|c|c|}
\hline $\begin{array}{l}\text { Behaviour } \\
\text { Analysed }\end{array}$ & Test & Component & Age (Days) & $\begin{array}{l}\text { Samples } \\
\text { Dimensions }\end{array}$ & $\begin{array}{l}\text { Requirements to ETICS } \\
\text { Performance [2] and Aim of Tests }\end{array}$ \\
\hline \multirow[t]{2}{*}{$\begin{array}{l}\text { Water } \\
\text { behaviour }\end{array}$} & $\begin{array}{l}\text { Water absorption } \\
\text { by capillarity }\end{array}$ & ETICS & 28 & $30 \mathrm{~cm} \times 30 \mathrm{~cm}$ & $\begin{array}{l}\text { ETICS are considered resistant to } \\
\text { water penetration if the water } \\
\text { absorbed by a system with or without } \\
\text { finishing coat (the surface in contact } \\
\text { with water is the base coat) after } 1 \mathrm{~h} \\
\text { is less than or equal to } 1 \mathrm{~kg} / \mathrm{m}^{2} \text {. } \\
\text { Systems without finishing allow to } \\
\text { analyse if the base coat resists water } \\
\text { penetration without the contribution } \\
\text { of the finishing coat. }\end{array}$ \\
\hline & $\begin{array}{l}\text { Water vapour } \\
\text { permeability }\end{array}$ & $\begin{array}{c}\text { Render } \\
\text { (reinforced } \\
\text { base coat }+ \\
\text { finishing coat) }\end{array}$ & 28 & $10 \mathrm{~cm} \times 10 \mathrm{~cm}$ & $\begin{array}{l}\text { To avoid water vapour condensation, } \\
\text { the resistance to water vapour } \\
\text { diffusion of the rendering system } \\
\text { (reinforced base coat and finishing } \\
\text { coat) should normally not exceed } \\
2.0 \mathrm{~m} \text { (based on EN 12086) [24]. }\end{array}$ \\
\hline
\end{tabular}


Table 2. Cont.

\begin{tabular}{|c|c|c|c|c|c|}
\hline $\begin{array}{l}\text { Behaviour } \\
\text { Analysed }\end{array}$ & Test & Component & Age (Days) & $\begin{array}{c}\text { Samples } \\
\text { Dimensions }\end{array}$ & $\begin{array}{c}\text { Requirements to ETICS } \\
\text { Performance [2] and Aim of Tests }\end{array}$ \\
\hline \multirow[t]{3}{*}{$\begin{array}{l}\text { Mechanical } \\
\text { behaviour }\end{array}$} & Impact resistance & ETICS & $\begin{array}{l}\text { After } \\
\text { artificial } \\
\text { ageing }\end{array}$ & $3 \mathrm{~m} \times 2 \mathrm{~m}$ & $\begin{array}{l}\text { Test to analyse impact resistance. The } \\
\text { presence of any micro cracks or } \\
\text { cracks after hard body impact with } \\
\text { steel ball } 3 \text { J and } 10 \text { J: Category I-no } \\
\text { deterioration with } 3 \text { J and } 10 \mathrm{~J} \text {, } \\
\text { Category II-no deterioration with } 3 \mathrm{~J} \\
\text { and rendering not penetrated with } \\
10 \mathrm{~J} \text {, and Category III-rendering not } \\
\text { penetrated with } 3 \mathrm{~J} \text {. } \\
\text { The application height on the facade } \\
\text { is determined based on the impact } \\
\text { test results. } \\
\text { Use categories: Category I-zones } \\
\text { readily accessible at ground level to } \\
\text { the public and vulnerable to hard } \\
\text { body impacts but not subjected to } \\
\text { abnormally rough use; Category } \\
\text { II-zones liable to impacts from } \\
\text { thrown or kicked objects, but in } \\
\text { public locations where the height of } \\
\text { the system will limit the size of the } \\
\text { impact or at lower levels where } \\
\text { access to the building is primarily to } \\
\text { those with some incentive to exercise } \\
\text { care; and Category III-zones not } \\
\text { likely to be damaged by normal } \\
\text { impacts caused by people or by } \\
\text { thrown or kicked objects. }\end{array}$ \\
\hline & $\begin{array}{l}\text { Bond strength } \\
\text { (between } \\
\text { insulation to base } \\
\text { coat }+ \text { mesh) }\end{array}$ & ETICS & $\begin{array}{l}\text { After } \\
\text { artificial } \\
\text { ageing }\end{array}$ & $3 \mathrm{~m} \times 2 \mathrm{~m}$ & Results shall be at least equal to \\
\hline & $\begin{array}{l}\text { Bond strength } \\
\text { (between } \\
\text { adhesive to } \\
\text { insulation) }\end{array}$ & $\begin{array}{l}\text { Adhesive } \\
\text { and } \\
\text { insulation } \\
\text { (for bonding } \\
\text { systems) }\end{array}$ & 28 & $1 \mathrm{~m} \times 0.5 \mathrm{~m}$ & $\begin{array}{l}0.08 \mathrm{~N} / \mathrm{mm}^{2}(\mathrm{MPa}) \text { with } \\
\text { cohesive or adhesive rupture. }\end{array}$ \\
\hline \multirow[b]{2}{*}{$\begin{array}{l}\text { Acoustic and } \\
\text { thermal comfort }\end{array}$} & Airborne sound & ETICS & 28 & $10 \mathrm{~m}^{2}$ & $\begin{array}{c}\text { Declared value of } \Delta \mathrm{R}_{\mathrm{W} \text {,direct }} \\
\left(\Delta \mathrm{R}_{\mathrm{W} \text {,direct }}=\mathrm{R}_{\mathrm{W} \text {,with }}-\mathrm{R}_{\mathrm{W} \text {,without }}\right) \\
(\text { Based on EN ISO 10140-2) [25] }\end{array}$ \\
\hline & $\begin{array}{l}\text { Thermal } \\
\text { resistance }\end{array}$ & $\begin{array}{l}\text { Insulation } \\
\text { and ETICS }\end{array}$ & - & - & $\begin{array}{c}\text { Insulation product with a maximum } \\
\text { thermal conductivity of } 0.065 \mathrm{~W} / \mathrm{m} \cdot \mathrm{K} \text {. } \\
\text { Declared value of thermal resistance. } \\
\text { The minimum thermal resistance of } \\
\text { the ETICS shall exceed } 1 \mathrm{~m}^{2} \cdot \mathrm{K} / \mathrm{W} \text {. } \\
\mathrm{R}_{\mathrm{ETICS}}=\mathrm{R}_{\text {insulation }}+\mathrm{R}_{\text {render }} \\
{\left[\left(\mathrm{m}^{2} \cdot \mathrm{K}\right) / \mathrm{W}\right],\left(\mathrm{R}_{\text {render }} \text { is about }\right.} \\
\left.0.02 \mathrm{~m}^{2} \cdot \mathrm{K} / \mathrm{W}\right) \text { (According to } \\
\text { EN ISO 6946) [26] }\end{array}$ \\
\hline
\end{tabular}


Table 2. Cont.

\begin{tabular}{|c|c|c|c|c|c|}
\hline $\begin{array}{l}\text { Behaviour } \\
\text { Analysed }\end{array}$ & Test & Component & Age (Days) & $\begin{array}{c}\text { Samples } \\
\text { Dimensions }\end{array}$ & $\begin{array}{c}\text { Requirements to ETICS } \\
\text { Performance [2] and Aim of Tests }\end{array}$ \\
\hline Durability & $\begin{array}{l}\text { Visual aspect } \\
\text { (during } \\
\text { hygrothermal } \\
\text { test) }\end{array}$ & ETICS & $\begin{array}{l}\text { After } \\
\text { artificial } \\
\text { ageing }\end{array}$ & $3 \mathrm{~m} \times 2 \mathrm{~m}$ & $\begin{array}{l}\text { According to ETAG, ETICS is } \\
\text { predicted to have working life of } \\
25 \text { years. Durability was analysed } \\
\text { through visual aspect after } \\
\text { hygrothermal test. This test simulates } \\
\text { accelerated artificial ageing. Systems } \\
\text { were subjected to heat-rain and } \\
\text { heat-cold cycles. } \\
\text { None of the following defects } \\
\text { detected during the testing: blistering } \\
\text { or peeling of any finishing, failure or } \\
\text { cracking associated with joints } \\
\text { between insulation product boards or } \\
\text { profiles fitted with ETICS, } \\
\text { detachment of render and cracking } \\
\text { allowing water penetration to the } \\
\text { insulation layer. }\end{array}$ \\
\hline
\end{tabular}

Classification obtained of reaction to fire conditions according to the type and height building where ETICS is applied.

The reaction to fire was tested according to EN 13823 [27] and EN 11925-2 [28] and classified according to EN 13501-1+A1 [29].

$\mathrm{B}$ and $\mathrm{C}$ : class reaction to fire. Additional classification of smoke production: s3 (no limitation of smoke production required), s2 (the total smoke production as well as the ratio of increase in smoke production are limited. This is applicable to systems for which no performance is declared and systems not satisfying the criterion defined in s1), and s1

Fire resistance Reaction to fire $\quad$ ETICS $\quad 28 \quad 1 \mathrm{~m} \times 1.5 \mathrm{~m}$ (more demanding criteria than s2 are satisfied. The system satisfies the following criterion: smoke $\leq 750 \% \times$ minutes). Additional classification of production of flaming droplets and/or particles: $\mathrm{d} 2$ (no limitation), d1 (no flaming droplets/particles persisting longer than a given time occurred), d0 (no flaming droplets/particles occurred). B-s1,d0 and B-s2,d0: these classifications were considered satisfactory according to Portuguese regulations for ETICS applied on buildings up to $28 \mathrm{~m}$ high.

C-s1,d0 and C-s2,d0: these categories limit the application field of the systems, according with the current standard for small buildings (less than $9 \mathrm{~m}$ ). 


\section{Results and Discussion}

\subsection{Water Behaviour}

The water behaviour of the ETICS was evaluated by water absorption and by equivalent air thickness. The absorption was evaluated for systems with and without finishing coats, and equivalent air thickness was evaluated for specimens composed of reinforced base coat and finishing coat (in Table 3). The edges of the samples were sealed, including the insulation product.

Table 3. Capillarity and water vapour permeability tests.

\begin{tabular}{|c|c|c|c|c|c|c|c|c|}
\hline \multirow{2}{*}{ ETICS } & & \multirow{2}{*}{ Components } & & \multirow{2}{*}{$\begin{array}{c}\text { Quantities } \\
\text { Applied } \\
\left(\mathbf{k g} / \mathrm{m}^{2}\right)- \\
\text { Mortar of } \\
\text { Base Coat + } \\
\text { Finishing Coat }\end{array}$} & \multicolumn{2}{|c|}{$\begin{array}{l}\text { ETICS Samples (with or } \\
\text { without Finishing Coat) }\end{array}$} & \multirow{2}{*}{$\begin{array}{c}\text { Samples } \\
\text { Composed by } \\
\text { Render } \\
\text { (Reinforced } \\
\text { Base Coat }+ \\
\text { Finishing Coat) } \\
\\
\text { Equivalent Air } \\
\text { Thickness - Sd (m) } \\
\text { Average }\end{array}$} & \multirow{2}{*}{$\begin{array}{c}\text { (ETICS) } \\
\\
\mu\end{array}$} \\
\hline & & & & & $\begin{array}{c}\text { Water } \\
\text { Absorption } \\
\text { after } 1 \mathrm{~h} \\
\left(\mathrm{~kg} / \mathrm{m}^{2}\right)- \\
\text { Average and } \sigma\end{array}$ & $\begin{array}{c}\text { Capillarity } \\
\text { Coefficient } \\
\text { after } 1 \mathrm{~h} \\
\left(\mathrm{~kg} / \mathrm{m}^{2} \cdot \mathrm{s}^{0.5}\right) \text { - } \\
\text { Average }\end{array}$ & & \\
\hline ETICS 1 & \multirow{2}{*}{ EPS } & \multirow{4}{*}{ C } & - & 5.59 & $0.17 \pm 0.01$ & 0.003 & ND & ND \\
\hline ETICS 2 & & & A & $5.59+1.43$ & $0.08 \pm 0.04$ & 0.001 & 1.42 & 47.3 \\
\hline ETICS 3 & \multirow{2}{*}{ ICB } & & - & 6.97 & $0.80 \pm 0.02$ & 0.013 & ND & ND \\
\hline ETICS 4 & & & A & $6.97+1.44$ & $0.73 \pm 0.04$ & 0.012 & 1.42 & 42.2 \\
\hline ETICS 5 & \multirow{2}{*}{ EPS } & \multirow{4}{*}{ C } & - & 3.50 & $0.04 \pm 0.01$ & 0.001 & ND & ND \\
\hline ETICS 7 & & & A & $3.50+0.23$ & $0.04 \pm 0.01$ & 0.001 & 1.03 & 27.9 \\
\hline ETICS 9 & \multirow{2}{*}{ ICB } & & - & 3.81 & $0.07 \pm 0.00$ & 0.001 & ND & ND \\
\hline ETICS 11 & & & A & $3.81+4.49$ & $0.06 \pm 0.01$ & 0.001 & 1.03 & 13.5 \\
\hline ETICS 13 & \multirow{2}{*}{ EPS } & \multirow{4}{*}{$\mathrm{C}$} & - & 9.45 & $0.20 \pm 0.02$ & 0.003 & ND & ND \\
\hline ETICS 14 & & & A & $9.45+0.67$ & $0.04 \pm 0.01$ & 0.001 & 0.44 & 44.6 \\
\hline ETICS 15 & \multirow{2}{*}{ ICB } & & - & 8.93 & $0.09 \pm 0.01$ & 0.002 & ND & ND \\
\hline ETICS 16 & & & A & $8.93+0.54$ & $0.03 \pm 0.01$ & 0.001 & 0.44 & 35.3 \\
\hline ETICS 17 & \multirow{2}{*}{ EPS } & \multirow{2}{*}{ C } & - & 3.39 & $0.15 \pm 0.05$ & 0.003 & ND & ND \\
\hline ETICS 18 & & & $\mathrm{~A}$ & $3.39+1.95$ & $0.05 \pm 0.01$ & 0.001 & 0.71 & 38.2 \\
\hline ETICS 21 & \multirow{3}{*}{ ICB } & \multirow{3}{*}{$\mathrm{M}$} & - & 6.50 & $0.20 \pm 0.20$ & 0.003 & ND & ND \\
\hline ETICS 22 & & & $\mathrm{~A}$ & $6.50+1.48$ & $0.10 \pm 0.11$ & 0.002 & 0.76 & 42.5 \\
\hline ETICS 23 & & & $\mathrm{~S}$ & $6.50+5.40$ & $0.05 \pm 0.01$ & 0.001 & 1.33 & 33.3 \\
\hline ETICS 25 & \multirow{2}{*}{ EPS } & \multirow{2}{*}{ C } & - & 2.82 & $0.10 \pm 0.03$ & 0.002 & ND & ND \\
\hline ETICS 26 & & & A & $2.82+2.19$ & $0.05 \pm 0.01$ & 0.001 & 0.38 & 39.9 \\
\hline ETICS 29 & \multirow{3}{*}{ ICB } & \multirow{3}{*}{$C L$} & - & 3.90 & $0.28 \pm 0.04$ & 0.005 & ND & ND \\
\hline ETICS 30 & & & A & $3.90+2.69$ & $0.36 \pm 0.17$ & 0.006 & 0.21 & 21.5 \\
\hline ETICS 31 & & & $\mathrm{AL}$ & $3.90+2.73$ & $0.14 \pm 0.04$ & 0.005 & 0.06 & 18.7 \\
\hline
\end{tabular}

EPS: expanded polystyrene; ICB: expanded cork; C: Cement-based mortar; M: Mixed binders-based mortar; CL: Mortar based on natural hydraulic lime, cement; A: Acrylic resins; S: Natural hydraulic lime based mortar + Paint based on silicate; AL: Air lime and hydraulic binder. ND: not determined.

Concerning the water absorption, several conclusions were reached. We noticed that more than one component of ETICS influenced the water absorption of the mortars. 
At first, we noticed that systems with a finishing coat presented a lower water absorption than systems without a finishing coat, which was as expected. A clear influence of the finishing coat was verified. The finishing reduced the water absorption of the ETICS, which can be verified by comparing ETICS 1 with 2, ETICS 3 with 4 and so on. In systems 22 and 23 and 30 and 31, different finishing coats presented different water absorption values. The silicate and air lime + hydraulic binder finishing coat presented lower values than the acrylic finishing coat.

The finishing coat was not the only component that influenced water absorption, in fact the insulation materials also influenced the ETICS' absorption. Some of the systems with cork showed higher water absorption than the corresponding EPS systems (ETICS 3 and ETICS 4 by comparison with ETICS 1 and ETICS 2). However, in other cases the performance is similar, or sometimes, cork systems showed the best behaviour (ETICS 15 and ETICS 16 by comparison with ETICS 13 and ETICS 14). Within ICB systems, the base coats composed by cement mortars (ETICS 3, 9 and 15) presented lower values of absorption than mortars with mixed binders or with natural hydraulic lime (ETICS 21 and 29, respectively). In the case of EPS systems, the cement mortars presented very different values (ETICS 1, 5, 13, 17 and 25). Therefore, it was concluded that the base coat characteristics were the main factor influencing the water absorption. Finally, ETICS with cork may present very good performance concerning water absorption whenever the insulation material is well protected with adequate basecoats and finishing coats, similarly to EPS systems.

A study carried out by D'Orazio et al [30] on ETICS system with finishing coats based on acrylic obtained results between 0.0011 and $0.0071 \mathrm{~kg} / \mathrm{m}^{2} \cdot \mathrm{s}^{0.5}$. These values fell within the range of results obtained (shown in Table 3) in acrylic finishing coats, both for EPS systems and for cork systems.

According to ETAG 004 [2], to assess the tendency for water vapour condensations in the render (reinforced base coat + finishing coat), water vapour permeability tests were also carried out. In Table 3, the water vapour permeability test results on ETICS render systems (base coat + finishing coat) are presented. Thus, the water vapour performance evaluated by ETAG 004 does not depend on the insulation material. However, the values of the vapor diffusion resistance factor of cork panels are much lower than those of EPS panels of the same thickness (this difference is, in fact, about one third, as indicated by the $\mu$ value (see Table 1$)$ ).

Comparing renders of systems with different finishing coats, distinct values were found, as is the case of ETICS 30 and 31. Air lime finishing resulted in more permeable render systems than acrylic finishing applied on the same base coat. In the case of ETICS 22 and 23, the render with acrylic finishing had a better performance than natural hydraulic lime-based mortar + silicate-based paint. However, in these cases, the render system of ETICS 23 used higher finishing consumptions than render 22, which can justify the different results.

On the other side, comparing ETICS 26 with ETICS 30, which had a different base coat, it was noticed that ETICS 26 (with cement mortar) had a higher equivalent air thickness than ETICS 30 (mortar based on natural hydraulic lime and cement), namely, $0.38 \mathrm{~m}$ and $0.21 \mathrm{~m}$, respectively. This reduction of permeability is due to the different base coats. Although both ETICS have the same finishing coats, the base coat clearly influenced the permeability of the systems.

All renders of EPS and ICB ETICS presented values less than $2 \mathrm{~m}$, meaning that all systems are, according to the requirements of ETAG 004, below risk of interstitial condensation. However, considering the much lower water vapor diffusion resistance factor of the cork panels (about 30\% lower than EPS panels) and taking into account that the thermal conductivity of the two insulation materials is similar, this means that systems with cork present, in fact, lower global equivalent air thickness and are thus more permeable to water vapor. 
In summary, for the capillarity test, although water absorption values of some of ICB systems were higher than those of EPS systems, the values obtained after $1 \mathrm{~h}$ were less than $1 \mathrm{~kg} / \mathrm{m}^{2}$, so systems with ICB or EPS both verify the ETAG 004 requirements in presenting a barrier against water penetration.

As for the water vapour permeability test, only the render system of ETICS (according to ETAG 004) was analysed, which did not allow a direct comparison between the two types of systems (EPS and ICB). However, the air lime finishing (of ETICS 31) used in the ICB system showed a low equivalent air thickness value.

In short, more sustainable systems with cork insulation also managed to achieve good performances concerning water and water vapor, with low water absorption by capillarity (after $1 \mathrm{~h}$ ) and moderate equivalent air thickness.

\subsection{Mechanical Behaviour}

The mechanical behaviour of the ETICS was analysed by the impact resistance test and by the bond strength of base coat/insulation and adhesive/insulation (for bonded systems only) (Table 4 ).

In addition to the influence of the type of insulation, the variation of other components was also analysed: the incorporation of a second mesh in base coat, variation of base coat type and the possibility of using another type of finishing coat.

Comparing the impact performance of systems with one mesh and without finishing coat, similar performance was observed between cork ETICS and EPS systems (ETICS 9 by comparison with ETICS 5).

In systems without finishing coat and with incorporation of a second mesh, it was found that ICB systems had better results (ETICS 3 by comparison with ETICS 1) or similar impact performance (ETICS 10 and 15 by comparison with ETICS 6 and 13).

Systems with cork (ETICS 11) with one mesh with finishing coat also showed the same performance as systems with EPS (ETICS 7).

In systems with finishing coat and two meshes incorporated on the base coat, a similar category was obtained on system 12 with ICB (by comparison with ETICS 8 with EPS) and better category on system 16 with cork (by comparison with ETICS 14); on the other hand, a lower category was observed on ETICS 4 with cork (by comparison with ETICS 2).

Only in the case of systems 1 and 2 (EPS) and 15 and 16 (ICB), did the application of the finishing coat improve the impact performance. ETICS 5 (EPS), 9 (ICB) and 13 (EPS) maintained the same categories in relation to similar systems with finishing coat (ETICS 7, 11 and 14, respectively). ETICS 30 and 31 (ICB) with only variation of the finishing coat type, different categories were attained. With acrylic and air lime finishing, Category II and Category III were achieved, respectively. As mentioned in the study of Steinbauer et al [6], the best performance in impact was verified by the system with acrylic finishing. Due to the high organic percentage, the finishing material have greater flexibility, improving the impact performance.

Some ETICS with EPS and ICB proved to have a similar behaviour (ETICS 5 and 9, 6 and 10, 7 and 11, 8 and 12, 13 and 15), but in ETICS 1 and 3, 2 and 4, 14 and 16, different categories were also observed, no clear trend having been identified.

Systems with cork presented satisfactory performance to impact resistance; the results showed that it is possible to apply this type of systems to the entire facade of the building, including the lowest and most subject to shocks (in the case of 3,10, 24, and 32).

In Table 4, results of bond strength between the base coat and insulation material are also exhibited. In this test, the cut was carried out until the weakest component (insulation), so the results seem to depend mainly on the characteristics of the insulation material tensile strength (Table 1) [8]. ICB systems achieved performance of bond strength (in rig and samples) higher than the tensile strength value of the cork insulation panels (i.e. greater than $0.05 \mathrm{MPa}$ ), that is, the application of the base coat on the insulation panels apparently acted as consolidation of the system. However, in the EPS systems, bond strength values 
were lower than tensile strength values of the corresponding insulation panels $(0.20$ to $0.26 \mathrm{MPa}$ ). This was verified in systems with and without finishing.

Table 4. Hard body resistance and bond strength between base coat and insulation (on rig-after ageing).

\begin{tabular}{|c|c|c|c|c|c|c|c|c|c|}
\hline \multirow{3}{*}{ ETICS } & & \multirow{3}{*}{\multicolumn{2}{|c|}{ Components }} & & \multicolumn{3}{|c|}{$\begin{array}{c}\text { ETICS Applied on Rig Submitted } \\
\text { Hygrothermal Cycles }\end{array}$} & \multirow{2}{*}{\multicolumn{2}{|c|}{$\begin{array}{c}\text { Samples Composed by } \\
\text { Adhesive and Insulation } \\
\text { with } 28 \text { Days } \\
\text { Bond between } \\
\text { Adhesive to Insulation }\end{array}$}} \\
\hline & & & & & \multirow{2}{*}{$\begin{array}{c}\begin{array}{c}\text { Impact } \\
\text { Resistance }\end{array} \\
\text { Categories }\end{array}$} & \multicolumn{2}{|c|}{$\begin{array}{l}\text { Bond between Base } \\
\text { Coat to Insulation }\end{array}$} & & \\
\hline & & & & & & $\begin{array}{l}\text { Strength } \\
\text { (MPa) }\end{array}$ & $\begin{array}{l}\text { Failure } \\
\text { Pattern }\end{array}$ & $\begin{array}{l}\text { Strength } \\
\text { (MPa) }\end{array}$ & $\begin{array}{l}\text { Failure } \\
\text { Pattern }\end{array}$ \\
\hline ETICS 1 & \multirow{2}{*}{ EPS } & \multirow{4}{*}{ C } & \multirow{4}{*}{ NR } & - & II & 0.22 & $\mathrm{C}$ & \multirow{2}{*}{0.17} & \multirow{2}{*}{$\mathrm{C}$} \\
\hline ETICS 2 & & & & A & I & 0.21 & $\mathrm{C}$ & & \\
\hline ETICS 3 & \multirow{2}{*}{ ICB } & & & - & I & 0.12 & $\mathrm{C}$ & \multirow{2}{*}{0.12} & \multirow{2}{*}{$\mathrm{C}$} \\
\hline ETICS 4 & & & & A & II & 0.15 & $\mathrm{C}$ & & \\
\hline ETICS 5 & \multirow{4}{*}{ EPS } & \multirow{8}{*}{$\mathrm{C}$} & $\mathrm{R}$ & \multirow{2}{*}{-} & II & 0.19 & $\mathrm{C}$ & \multirow{4}{*}{0.17} & \multirow{4}{*}{$\mathrm{C}$} \\
\hline ETICS 6 & & & RR & & I & 0.15 & $\mathrm{C}$ & & \\
\hline ETICS 7 & & & $\mathrm{R}$ & \multirow{2}{*}{ A } & II & 0.16 & $\mathrm{C}$ & & \\
\hline ETICS 8 & & & RR & & II & 0.16 & $\mathrm{C}$ & & \\
\hline ETICS 9 & \multirow{4}{*}{ ICB } & & $\mathrm{R}$ & \multirow{2}{*}{-} & II & 0.11 & $\mathrm{C}$ & \multirow{4}{*}{0.17} & \multirow{4}{*}{$\mathrm{A} / \mathrm{B} / \mathrm{C}$} \\
\hline ETICS 10 & & & RR & & I & 0.11 & $\mathrm{~A} / \mathrm{C}$ & & \\
\hline ETICS 11 & & & $\mathrm{R}$ & \multirow{2}{*}{ A } & II & 0.12 & $\mathrm{C}$ & & \\
\hline ETICS 12 & & & RR & & II & 0.12 & $\mathrm{~A} / \mathrm{C}$ & & \\
\hline ETICS 13 & \multirow{2}{*}{ EPS } & \multirow{4}{*}{ C } & \multirow{4}{*}{ RR } & - & III & 0.18 & $\mathrm{C}$ & \multirow{2}{*}{ ND } & \multirow{2}{*}{ ND } \\
\hline ETICS 14 & & & & A & III & 0.14 & $\mathrm{C}$ & & \\
\hline ETICS 15 & & & & - & III & 0.11 & $\mathrm{~A} / \mathrm{C}$ & & \\
\hline ETICS 16 & KD & & & A & II & 0.10 & $\mathrm{~A} / \mathrm{C}$ & ND & IVD \\
\hline ETICS 19 & EPS & $\mathrm{C}$ & & - & II & 0.12 & A & 0.17 & $\mathrm{C}$ \\
\hline ETICS 24 & ICB & M & $10 \pi$ & & I & 0.10 & $\mathrm{C}$ & 0.08 & $\mathrm{C}$ \\
\hline ETICS 25 & & & & - & II & 0.18 & $\mathrm{C}$ & & \\
\hline ETICS 26 & EDC & $r$ & 10 & A & - & 0.17 & $\mathrm{C}$ & & \\
\hline ETICS 27 & Lit & 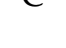 & & - & II & 0.15 & $\mathrm{C}$ & 0.27 & 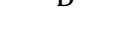 \\
\hline ETICS 28 & & & $10 \pi$ & A & - & 0.17 & $\mathrm{C}$ & & \\
\hline ETICS 29 & & & & - & - & 0.09 & $\mathrm{C}$ & & \\
\hline ETICS 30 & ICD & & $\mathrm{N}$ & A & II & 0.12 & A & & C \\
\hline ETICS 31 & DD & CL & & $\mathrm{AL}$ & III & 0.20 & A & 0.10 & 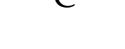 \\
\hline ETICS 32 & & & NR & - & I & 0.10 & $\mathrm{C}$ & & \\
\hline
\end{tabular}

C: Cement based mortar; M: Mixed binders-based mortar; CL: Mortar based on natural hydraulic lime, cement; A: Acrylic resins; AL: Air lime, hydraulic binder. N: normal mesh; NN: double normal mesh; NR: Normal + Reinforced; R: Reinforced mesh; RR: double reinforced mesh. Failure Pattern: A-Adhesive between base coat and insulation, B-cohesive in adhesive, C-cohesive in insulation. ND: Not determined (mechanically fixed ETICS).

Systems with cork insulation with different base coats (24 and 32), showed similar values of bond strength. It could mean that the insulation has more influence than the base coat since the fracture is cohesive (C) within the insulation material.

In the bond strength test (on rig), the incorporation of a second mesh in the system with EPS (ETICS 6 by comparison with ETICS 5) had worse results in some cases, but in 
the case of systems with cork, similar results were obtained (ETICS 9 in comparison with 10, ETICS 11 in comparison with 12, ETICS 29 in comparison with 32).

Generally, in systems with cork, the results did not appear to have been affected. As the fracture was predominantly cohesive within the insulation, the results were consistent with tensile strength perpendicular to the faces of the respective insulation materials (Table 1), so the addition of a second mesh had no influence [8].

Generally, for all systems, the values of bond strength between base coat and insulation board were greater than $0.08 \mathrm{MPa}$. Additionally, most of the results had a $\mathrm{C}$ failure pattern (cohesive) or an A/C (adhesive and cohesive) within the most fragile component.

Bond strength between adhesive and insulation board is only possible to determine on bonded systems; this makes it possible to analyse the connection between the adhesive and insulation. In general, in the studied ETICS, cohesive failure was predominant. The characteristics of the insulation material were also decisive. The same mortar was applied on different insulations (ETICS 1 e 3, 5 and 9), therefore the bond strength disparity values showed the clear influence of the insulation material. ETICS 1, 5 and 19, with the same insulation EPS and different cement mortars as base coats, showed similar results. In case of system 25 , the value was higher because the rupture occurred within the mortar. In ICB systems with different base coats, results were close ( 0.08 to $0.12 \mathrm{MPa})$ but always higher than the tensile strength of the insulation material (Table 1). In system 9, with ICB, the result obtained was higher than the other cork systems because the rupture was not only in the insulation but also in the adhesive and between the base coat and insulation.

ETICS with cork managed to present impact resistance similar to the most commonly used systems with EPS. Good impact resistance allowed these systems to be applied from the lower areas of the facade with one mesh (ETICS 3) or two incorporated meshes (ETICS 10,24 and 32). Bond strength results greater than $0.12 \mathrm{~N} / \mathrm{mm}^{2}$ and cohesive failure showed good compatibility between the base coat and the cork insulation.

In short, in impact resistance, the best category-which was I-was obtained in both types of ETICS ICBs and EPSs, meaning that ICB has a similar performance in this test. In the bond strength test, as the results depend essentially on the type of insulation characteristics, the values of ICB ETICS were always lower than the values of EPS ETICS; however, the results were always (in rig and samples) higher than the tensile strength value of the cork insulation panels $(0.05 \mathrm{MPa})$ and higher than $0.08 \mathrm{MPa}$ (Guideline requirement [2]). Since the rupture is cohesive in the insulation board, ICB systems also achieve satisfactory behaviour.

\subsection{Thermal and Acoustic Comfort}

Thermal resistance results of all ETICS with EPS or ICB were greater than $1 \mathrm{~m}^{2} \cdot \mathrm{K} / \mathrm{W}$ (Table 5), which reflects an important contribution to thermal comfort. Thermal resistance of ETICS increased due to the continuous layer of insulation incorporated (as proven by the similar values of thermal resistance of the insulation and ETICS). Thermal resistance was calculated for the minimum values of thickness of thermal insulation boards, which were considered as having $40 \mathrm{~mm}$ thickness. The maximum values to be obtained depend on the insulation boards' thickness.

Although all ETICS investigated presented a good thermal resistance, the systems with ICB contributed in a decisive way not only to thermal insulation but also to airborne sound insulation, which is in contrast to EPS that did not improve this last characteristic. The airborne sound improvement of ICB ETICS applied on concrete blocks masonry was 6 (Table 5) compared to uncoated concrete blocks masonry. The influence of airborne sound depended essentially on the type of insulation material.

Based on the results obtained, the systems with ICB and EPS showed a satisfactory thermal behaviour. Regarding acoustic comfort, ICB systems have a notably strong contribution, which had also been noticed in another research [4]. 
Table 5. Thermal resistance calculation and airborne sound insulation test.

\begin{tabular}{|c|c|c|c|c|c|c|c|c|}
\hline \multirow[b]{2}{*}{ ETICS } & \multirow{2}{*}{\multicolumn{2}{|c|}{ Components }} & \multicolumn{3}{|c|}{ Thermal Comfort } & \multicolumn{3}{|c|}{ Acoustic Comfort } \\
\hline & & & $\begin{array}{l}\text { Thermal } \\
\text { Resistance } \\
\text { Insulation } \\
\left(\mathrm{m}^{2} \cdot \mathrm{K} / \mathrm{W}\right)\end{array}$ & $\begin{array}{l}\text { Thermal } \\
\text { Resistance } \\
\text { ETICS } \\
\left(\mathrm{m}^{2} \cdot \mathrm{K} / \mathrm{W}\right)\end{array}$ & $\begin{array}{c}\text { Masonry Block } \\
\text { Concrete } \\
\text { without } \\
\text { ETICS- } \\
\text { R }_{\text {W,with }}(\mathrm{dB})\end{array}$ & $\begin{array}{c}\text { Masonry Block } \\
\text { Concrete with } \\
\text { ETICS- } \\
R_{\mathrm{W} \text {,with }}(\mathrm{dB})\end{array}$ & $\begin{array}{c}\text { Insulation } \\
\text { Thickness } \\
\text { (mm) }\end{array}$ & $\begin{array}{c}\text { Airborne } \\
\text { Sound Im- } \\
\text { provement } \\
\Delta \text { RW,Direct } \\
=\text { RW, } \\
\text { with - RW, } \\
\text { without }\end{array}$ \\
\hline ETICS 1 & EPS & - & 1.03 & 1.05 & ND & ND & ND & ND \\
\hline ETICS 2 & EPS & A & 1.03 & 1.05 & ND & ND & ND & ND \\
\hline ETICS 3 & ICB & - & 1.00 & 1.02 & ND & ND & ND & ND \\
\hline ETICS 4 & ICB & A & 1.00 & 1.02 & ND & ND & ND & ND \\
\hline ETICS 5 & EPS & - & 1.11 & 1.13 & ND & ND & ND & ND \\
\hline ETICS 6 & EPS & - & 1.11 & 1.13 & ND & ND & ND & ND \\
\hline ETICS 7 & EPS & A & 1.11 & 1.13 & ND & ND & ND & ND \\
\hline ETICS 8 & EPS & $\mathrm{A}$ & 1.11 & 1.13 & ND & ND & ND & ND \\
\hline ETICS 9 & ICB & - & 1.00 & 1.02 & ND & ND & ND & ND \\
\hline ETICS 10 & ICB & - & 1.00 & 1.02 & ND & ND & ND & ND \\
\hline ETICS 11 & ICB & A & 1.00 & 1.02 & ND & ND & ND & ND \\
\hline ETICS 12 & ICB & A & 1.00 & 1.02 & ND & ND & ND & ND \\
\hline ETICS 13 & EPS & - & 1.11 & 1.13 & 44 & 45 & 50 & 1 \\
\hline ETICS 14 & EPS & A & 1.11 & 1.13 & 44 & 45 & 50 & 1 \\
\hline ETICS 15 & ICB & - & 1.00 & 1.02 & 44 & 50 & 50 & 6 \\
\hline ETICS 16 & ICB & A & 1.00 & 1.02 & 44 & 50 & 50 & 6 \\
\hline ETICS 17 & EPS & - & 1.11 & 1.13 & 44 & 44 & 60 & 0 \\
\hline ETICS 18 & EPS & A & 1.11 & 1.13 & 44 & 44 & 60 & 0 \\
\hline ETICS 19 & EPS & - & 1.11 & 1.13 & 44 & 44 & 60 & 0 \\
\hline ETICS 20 & EPS & A & 1.11 & 1.13 & 44 & 44 & 60 & 0 \\
\hline ETICS 21 & ICB & - & 1.00 & 1.02 & 44 & 50 & 60 & 6 \\
\hline ETICS 22 & ICB & A & 1.00 & 1.02 & 44 & 50 & 60 & 6 \\
\hline ETICS 23 & ICB & $S$ & 1.00 & 1.02 & 44 & 50 & 60 & 6 \\
\hline ETICS 24 & ICB & - & 1.00 & 1.02 & 44 & 50 & 60 & 6 \\
\hline ETICS 25 & EPS & - & 1.11 & 1.13 & ND & ND & ND & ND \\
\hline ETICS 26 & EPS & A & 1.11 & 1.13 & ND & ND & ND & ND \\
\hline ETICS 27 & EPS & - & 1.11 & 1.13 & ND & ND & ND & ND \\
\hline ETICS 28 & EPS & A & 1.11 & 1.13 & ND & ND & ND & ND \\
\hline ETICS 29 & ICB & - & 1.00 & 1.02 & 48 & 51 & 50 & 3 \\
\hline ETICS 30 & ICB & A & 1.00 & 1.02 & 48 & 51 & 50 & 3 \\
\hline ETICS 31 & ICB & $\mathrm{AL}$ & 1.00 & 1.02 & 48 & 51 & 50 & 3 \\
\hline ETICS 32 & ICB & - & 1.00 & 1.02 & 48 & 51 & 50 & 3 \\
\hline
\end{tabular}




\subsection{Durability}

During and after the end of the hygrothermal test, none of the following defects were detected: blistering or peeling of any finishing, failure or cracking associated with joints between insulation boards or profiles fitted with ETICS, detachment of render or cracking allowing water penetration to the insulation layer. Results allowed to predict ETICS behaviour when applied on facades subjected to weathering and their performance over time. All systems showed satisfactory behaviour after accelerated artificial ageing, which may indicate that applied in situ they will present good performance. Hygrothermal simulation with accelerated ageing test to evaluate the degradation mechanisms in order to assess durability were also performed by other researchers [31].

The most sustainable systems (with cork as an insulation material) show good results after hygrothermal cycles, so it is foreseen that they present good durability in practice, such as systems with EPS.

\subsection{Fire Resistance}

In Table 6, the ETICS results of reaction to fire are exhibited. All insulation boards presented E class of fire reaction. All systems achieved a better class than the respective insulation material, so base coat and finishing coat characteristics were important. In generally, EPS and ICB systems evidenced a satisfactory reaction to fire. Thus, the finishing coat played a crucial role in the reaction to fire. The variation of insulation (EPS vs ICB) did not influence the final reaction to fire class of the systems (B or C). Most of ETICS obtained B class, and this classification was considered satisfactory according to Portuguese regulations for exterior walls renders of buildings up to $28 \mathrm{~m}$ high. ETICS 2 and 4 attained $\mathrm{C}$ class, and this category limits the field of application of the systems, according with the same regulation, to small buildings (less than $9 \mathrm{~m}$ ).

Table 6. Reaction to fire test.

\begin{tabular}{|c|c|c|c|c|c|}
\hline \multirow[b]{2}{*}{ ETICS } & \multirow{2}{*}{$\begin{array}{c}\text { Insulation } \\
\text { Type }\end{array}$} & \multicolumn{3}{|c|}{ Components } & \multirow{2}{*}{$\begin{array}{c}\text { Reaction to } \\
\text { Fire of } \\
\text { ETICS }\end{array}$} \\
\hline & & $\begin{array}{c}\text { Thickness } \\
\text { (mm) }\end{array}$ & Base Coat & $\begin{array}{c}\text { Finishing } \\
\text { Coat }\end{array}$ & \\
\hline ETICS 2 & EPS & 100 & \multirow{2}{*}{ C } & $\mathrm{A}$ & C-s2,d0 \\
\hline ETICS 4 & ICB & 100 & & A & C-s1,d0 \\
\hline ETICS 7 & EPS & 80 & \multirow{2}{*}{$\mathrm{C}$} & $\mathrm{A}$ & B-s2,d0 \\
\hline ETICS 11 & ICB & 80 & & A & B-s1,d0 \\
\hline ETICS 14 & EPS & 80 & \multirow{2}{*}{$\mathrm{C}$} & $\mathrm{A}$ & B-s1,d0 \\
\hline ETICS 16 & ICB & 100 & & A & B-s1,d0 \\
\hline ETICS 18 & EPS & 100 & $\mathrm{C}$ & $\mathrm{A}$ & B-s1,d0 \\
\hline ETICS 22 & ICB & 100 & \multirow{2}{*}{ M } & $\mathrm{A}$ & B-s1,d0 \\
\hline ETICS 23 & ICB & 100 & & $\mathrm{~S}$ & B-s1,d0 \\
\hline ETICS 26 & EPS & 80 & $\mathrm{C}$ & A & B-s1,d0 \\
\hline ETICS 30 & ICB & 100 & \multirow{2}{*}{$\mathrm{CL}$} & $\mathrm{A}$ & B-s1,d0 \\
\hline ETICS 31 & ICB & 100 & & $\mathrm{AL}$ & B-s1,d0 \\
\hline
\end{tabular}

C: Cement based mortar; M: Mixed binders-based mortar; CL: Mortar based on natural hydraulic lime, cement; A: Acrylic resins; AL: Air lime, hydraulic binder.

However, the variation of the insulation materials of systems 2 and 4 and 7 and 11, resulted in different smoke production. ETICS 4 and 11 presented additional classification of smoke production s1 more demanding than s2. However, ETICS 2 and 7 accomplished the criterion (smoke $\leq 750 \% \times$ minutes (Table 2)).

Fire reaction tests on ETICS with EPS and acrylic finishing coat were also carried out by Milovanovi et al. [32] and obtained a classification of B-s2,d0. 
It was concluded that the results of the fire tests for the systems with ICB and EPS were similar for both insulation materials except in some cases that showed lower smoke production for ICB systems. Classification of larger differences seems to depend essentially on the rendering system, as between ETICS 2 and 7 or ETICS 4 and 11.

In summary, more sustainable systems with cork also showed adequate fire performance.

\section{Conclusions}

ETICS with insulation cork boards are more sustainable systems compared with ETICS with more commonly used insulation materials, such as EPS.

Due to environmental concerns, ETICS with more sustainable materials are being introduced in the market. In order to analyse the technical performance of these systems, the suitability for use and durability of 32 ETICS were analysed through an experimental campaign. The results were interpreted according to the requirements established by ETAG 004 and systems with cork insulation boards compared with systems with EPS.

The water penetration resistance was analysed. A system with ICB and finishing with silicate paint showed good water performance, with very low water absorption value. The systems with ICB showed good water behaviour when applied with a rendering system (base coat and finishing coat) adequate to protect the insulation panels. Concerning the water vapour performance, it was verified that the water vapour diffusion resistance factors $(\mu)$ of the cork panels are much lower than those of EPS panels, thus contributing to easier release of moisture in vapour form. In fact, coating systems with low diffusion resistance are to be preferred as they minimize water condensation inside the walls.

All systems were submitted to artificial ageing through a hygrothermal test (heat-rain and heat-cold cycles). After the weathering cycles, the systems presented no defects. The results were satisfactory in both ICB and EPS systems.

Impact resistance is a very important test, as its results allow the system to be classified in a category that defines its field of application, for example the height of application of the system on the facade. The combination of the results of the impact test of $3 \mathrm{~J}$ and $10 \mathrm{~J}$ allowed to obtain categories between I to III for all the systems. Clear differences were not found between EPS and cork systems. Some systems with ICB presented category I, the best classification, allowing the system to be applied throughout the facade, even in the lowest areas and exposed to impact.

In bond strength test, when the failure was cohesive (in the insulation product), the result essentially depended on the characteristics of the insulation material, fundamentally on the tensile strength of the insulation. Systems with ICB obtained better results (of bond strength) than the insulation panel (tensile strength), that is, the application of a base coat provided a consolidation effect on the insulation material by the mortar. This test allowed us to verify the good compatibility between components and in the case of bonded systems, good adhesion to the substrate.

The calculations to determine the thermal resistance showed that systems with ICB, as well as systems with EPS, significantly improved thermal comfort. The results of the test to determine the air-borne sound allowed us to clearly verify the higher contribution of ETICS with ICB by comparison to ETICS with EPS.

Considering the results of the extensive experimental campaign carried out, it is possible to conclude that natural, more sustainable insulation materials that reduce the environmental footprint, such as panels of cork insulation, may be used in ETICS with satisfactory global performance, similar to the EPS systems commonly applied.

Author Contributions: Conceptualization, S.M., R.V. and C.B.F.; investigation, S.M. and R.V.; writing—original draft preparation, S.M., R.V. and C.B.F.; writing—review and editing, R.V. and C.B.F. All authors have read and agreed to the published version of the manuscript.

Funding: This research was funded National Laboratory for Civil Engineering and FCT_Foundation for Science and Technology (of Portugal).

Institutional Review Board Statement: Not applicable. 
Informed Consent Statement: Not applicable.

Data Availability Statement: Data is contained within the article.

Acknowledgments: This work has been developed in the scope of the Project REuSE-Wall coatings for rehabilitation: safety and sustainability, ref. 0803/112/19461, financed by LNEC, and of the Project WGB_Shield-Shielding building' facades on cities revitalization. Triple-resistance for water, graffiti and biocolonization of external thermal insulation systems, ref. PTDC/ECI-EGC/30681/2017, financed by FCT-Foundation for Science and Technology (of Portugal) and CERIS Research Centre (Instituto Superior Técnico-University of Lisbon).

Conflicts of Interest: The authors declare no conflict of interest.

\section{References}

1. Aditya, L.; Mahlia, T.M.I.; Rismanchi, B.; Ng, H.M.; Hasan, M.H.; Metselaar, H.S.C.; Muraza, O.; Aditiya, H.B. A review on insulation materials for energy conservation in buildings. Renew. Sustain. Energy Rev. 2017, 73, 1352-1365. [CrossRef]

2. EOTA. Guideline for European Approval of External Thermal Insulation Composite Systems (ETICS) with Rendering-ETAG 004; EOTA: Brussels, Belgium, 2013.

3. Fernandes, C.; de Brito, J.; Cruz, C.O. Architectural integration of ETICS in building rehabilitation. J. Build. Eng. 2016, 5, 178-184. [CrossRef]

4. Veiga, M.R.; Malanho, S. Facade Insulation and Waterproofing: Contribution of Renders (in Portuguese). Construção Magazine $n^{\circ}$ 54-Isolamento e Impermeabilização 2013, 54, 22-25.

5. Guedes, M.C.; Matias, L.; Santos, C.P. Thermal comfort criteria and building design: Field work in Portugal. Renew. Energy 2009, 34, 2357-2361. [CrossRef]

6. Schiavoni, S.; D’Alessandro, F.; Bianchi, F.; Asdrubali, F. Insulation materials for the building sector: A review and comparative analysis. Renew. Sustain. Energy Rev. 2016, 62, 988-1011. [CrossRef]

7. Simões, I.; Simões, N.; Tadeu, A. Thermal delay simulation in multilayer systems using analytical solutions. Energy Build. 2012, 49, 631-639. [CrossRef]

8. Malanho, S.; Veiga, R. Bond strength between layers of ETICS-Influence of the characteristics of mortars and insulation materials. J. Build. Eng. 2020, 28, 101021. [CrossRef]

9. Liisma, E.; Lõhmus, G.; Raado, L. The effect of temperature and humidity on the permanence of external thermal insulation composite systems. Procedia Eng. 2015, 108, 340-348. [CrossRef]

10. Barreira, E.; de Freitas, V.P. Experimental study of the hygrothermal behaviour of External Thermal Insulation Composite Systems (ETICS). Build. Environ. 2013, 63, 31-39. [CrossRef]

11. Artur, N.; Paweł, K.; Artur, M. Properties of expanded graphite polystyrene damaged by the impact of solar radiation. J. Build. Eng. 2021, 34, 1-8.

12. Šadauskiene, J.; Stankevičius, V.; Bliudžius, R.; Gailius, A. The impact of the exterior painted thin-layer render's water vapour and liquid water permeability on the moisture state of the wall insulating system. Constr. Build. Mater. 2009, 23, $2788-2794$. [CrossRef]

13. Norvaisiene, R.; Krause, P.; Buhagiar, V.; Burlingis, A.; Miskinis, K. Verification of external thermal insulation systems with composite thermal insulation and different renders in effect of hydrothermal stress. In Proceedings of the 9th InnovationsSustainability-Modernity-Openness Conference (ISMO20), Bialystok, Poland, 20-21 May 2020.

14. Parracha, J.L.; Borsoi, G.; Flores-Colen, I.; Veiga, R.; Nunes, L.; Dionísio, A.; Gomes, M.G.; Faria, P. Performance parameters of ETICS: Correlating water resistance, bio-susceptibility and surface properties. Constr. Build. Mater. 2020, 28, 101021. [CrossRef]

15. Institut Bauen and Umwelt e.V. (IBU). Environmental Product Declaration. Expanded Polystyrene (EPS) Foam Insulation (with Flame Retardant, Density $20 \mathrm{~kg} / \mathrm{m}^{3}$ ) (Declaration n. EPD-EUM-20160274-IBG1-EN); Institut Bauen and Umwelt e.V. (IBU): Berlin, Germany, 2017.

16. Environmental Construction Products Organisation (ECO). Environmental Product Declaration. Expanded Polystyrene (EPS) Foam Insulation (Density $25 \mathrm{~kg} / \mathrm{m}^{3}$ ) (Declaration n. ECO-EPS-00030101-1106); Environmental Construction Products Organisation (ECO): Bonn, Germany, 2011.

17. Institut Bauen and Umwelt e.V. (IBU). Environmental Product Declaration. Expanded Polystyrene (EPS) Foam Insulation (Density $30 \mathrm{~kg} / \mathrm{m}^{3}$ ) (Declaration n. EPD-EUM-20160272-IBG1-EN); Institut Bauen and Umwelt e.V. (IBU): Germany, Berlin, 2017.

18. Institut Bauen and Umwelt e.V. (IBU). Environmental Product Declaration. Extruded Polystyrene (XPS) Foam Insulation with Halogen Free Blowing Agent; (Declaration n. EPD-EXI-20190112-IBE1-EN); Institut Bauen and Umwelt e.V. (IBU): Germany, Berlin, 2019.

19. Sierra-Pérez, J.; Boschmonart-Rives, J.; Dias, A.C.; Gabarrell, X. Environmental implications of the use of agglomerated cork as thermal insulation in buildings. J. Clean. Prod. 2016, 126, 97-107. [CrossRef]

20. L. CEIFA Ambiente Environmental Product Declaration. Insulation Cork Boards. 2015. Available online: www.daphabitat.pt (accessed on 17 November 2020).

21. Silva, S.P.; Sabino, M.A.; Fernandas, E.M.; Correlo, V.M.; Boesel, L.F.; Reis, R.L. Cork: Properties, capabilities and applications. Int. Mater. Rev. 2005, 50, 345-365. [CrossRef] 
22. Silvestre, J.D.; Pargana, N.; de Brito, J.; Pinheiro, M.D.; Durão, V. Insulation cork boards-environmental life cycle assessment of an organic construction material. Materials 2016, 9, 394. [CrossRef] [PubMed]

23. Malanho, S.; Veiga, R. Behaviour Analysis of Thermal Insulation Systems with Cork. In Proceedings of the CLB-MCS 2014Congresso Luso-Brasileiro de Materiais de Construção Sustentáveis, Guimarães, Portugal, 5-7 March 2014. (In Portuguese).

24. CEN. Thermal insulating products for building applications. In Determination of Water Vapour Transmission Properties; EN 12086; CEN: Brussels, Belgium, 2013.

25. CEN. Acoustics_Laboratory Measurement of Sound Insulation of Building Elements_Part 2: Measurement of Airborne Sound Insulation; ISO 10140-2; CEN: Brussels, Belgium, 2010.

26. CEN. Building Components and Building Elements—Thermal Resistance and Thermal Transmittance-Calculation Methods; EN 6946; CEN: Brussels, Belgium, 2017.

27. CEN. Reaction to fire tests for building products. In Building Products Excluding Floorings Exposed to the Thermal Attack by a Single Burning Item; EN 13823+A1; CEN: Brussels, Belgium, 2010.

28. CEN. Reaction to Fire Tests—Ignitability of Products Subjected to Direct Impingement of Flame—Part 2: Single-Flame Source Test; EN 11925-2; CEN: Brussels, Belgium, 2010.

29. CEN. Fire Classification of Construction Products and Building Elements_Part 1: Classification Using Data from Reaction to Fire Tests; EN 13501-1+A1; CEN: Brussels, Belgium, 2018.

30. D’Orazio, M.; Cursio, G.; Graziani, L.; Aquilanti, L.; Osimani, A.; Clementi, F.; Yepremian, C.; Lariccia, V.; Amoroso, S. Effects of water absorption and surface roughness on the bioreceptivity of ETICS compared to clay bricks. Build. Environ. 2014, 77, 20-28. [CrossRef]

31. Maia, J.; Ramos, N.M.M.; Veiga, R. A new durability assessment methodology of thermal mortars applied in multilayer rendering systems. Constr. Build. Mater. 2019, 222, 654-663. [CrossRef]

32. Milovanović, B.; Pečur, I.B.; Bjegović, D.; Boström, L.; Hajduković, M. ETICS fire performance test. In Proceedings of the Fifth International Workshop on Performance, Protection \& Strengthening of Structures Under Extreme Loading, East Lansing, MI, USA, 28-30 June 2015. 